\title{
The European union as a Trade Power
}

Sophie Meunier

Woodrow Wilson School

Bendheim 018

Princeton University

Princeton, NJ 08544, USA

+1 609 258-4863

smeunier@princeton.edu

www.princeton.edu/ smeunier
Kalypso Nicolaidis

Oxford University

St Antony's College

Oxford OX2 ^JF

441865274469

Kalypso.nicolaidis@sant.ox.ac.uk

http://users.ox.ac.uk/ ssfc0041

Chapter in The International Relations of the European Union, Christopher Hill and Michael Smith eds., forthcoming 2005. 


\section{Summary}

The EU is a formidable trade power. While trade liberalization internally and externally have always been the essence of European integration, successive enlargements and the creation of the European Single Market have turned the EU into the world's largest trade power. The EU is responsible for making trade policy through a complex decisionmaking process that has often been contested politically but allows it to speak on behalf of its members in international trade negotiations. This chapter argues that not only does the EU derive some inherent power from trade, but that it is also increasingly prone to use trade as the backbone of its normative power. As a result the EU is now becoming a world power through trade, as one of the major actors shaping the multilateral trade agenda, and using access to its market strategically in order to obtain political concessions from its commercial partners. This chapter explores the determinants of the EU's trade power (both inherent and normative) and examines the contribution of trade policy to the power of Europe in the international system, both in the context of the World Trade Organization and in the broader framework of international relations. 


\section{Introduction}

If there is any area in which the European Union (EU) has become an uncontested power in the international system, it is clearly in the field of trade policy. No wonder: trade is the EU's raison d'être. The objective of the 1957 Treaty of Rome was to create a customs union between the original six members of the European Community in which there would be no barriers to trade and a common external tariff would be applied to imports from third countries. From its very beginning, then, the Community became a single actor in international trade policy and almost immediately started talking on an equal footing with the United States in commercial negotiations. With its successive enlargements from six to twenty-five countries and the prosperous economies of its member states, the EU has become a formidable trade power and interlocutor in international trade negotiations.

Partly by design, partly by necessity, the EU entertains a very different relationship to power than the United States. It sees itself above all as a civilian and a normative, power, apt at using non-military tools to achieve its goals in the rest of the world (Duchêne, 1973; Hill, 1992; Stavridis, 2001; Nicolaidis and Howse, 2002; Manners, 2002). Trade is at the very core of the EU's civilian power. The sheer size of the European single market, which attracts the outside world both for the possibilities it offers and for the fear of being excluded, is an essential element of EU power. The collective character of European trade policy has enabled the EU to become a true rival to 
the United States. Yet the power of the EU in trade goes further that its impressive capacity to defend its own interests in international commercial negotiations. It also lies in its capacity to expand its own regulatory practices to the rest of the world and to use trade to promote internationally its own values and policies. In that the EU constitutes neither a rival to the US nor necessarily an ally, but it can be viewed as an "alternative" for countries seeking a power anchor when disagreeing with the US. The principled positions taken by the EU in the beef hormones and the ongoing Genetically Modified Organisms disputes are evidence of this new European propensity to seek to shape the global rules of the game according to its own internal compromises.

In keeping with the driving themes of this volume, the present chapter explores the determinants of the EU's trade power and examines the contribution of trade policy to the power of Europe in the international system, both in the context of the World Trade Organization and in the broader framework of international relations. In doing so we argue that it is crucial to distinguish between the inherent power derived from trade and the use of trade as the backbone of normative power. We start by recounting how the EU acquired and retained competence to represent the member states in trade policy, from the Treaty of Rome to the latest debate around a new European Constitution. Section 2 provides an overview of the EU trade policy-making process, while Section 3 explores how its recent enlargement may transform the trade power of the EU. Section 4 moves on to asking whether and how, on this institutional basis, the EU can credibly be presented as a champion of multilateralism, including in the context of dispute resolution in the WTO. We conclude by assessing the EU as a world power in trade and through trade. 


\section{The Road to European Competence in Trade}

The common commercial policy is the most prominent EU policy to have been under supranational competence from the very beginning. Whether in bilateral, regional or multilateral trade negotiations, Europe formally "speaks with one voice” and negotiates through one agent, the European Commission. The very idea that nation-states could give up such a key area of their external affairs was, and continues to be, revolutionary. But the granting of competence over trade to the supranational authority has not always been without political controversy (Meunier and Nicolaidis 1999). While the expansion of the global trade agenda during the 1990s, notably to services, seemed to call for a parallel expansion of the scope of EU competence, several member states resisted further transfers of sovereignty, leading to a protracted battle over the issue of trade competence. This section explores the conflicts within the EU over the appropriate institutional design for trade policy-making as reflected in the balance between competences exclusive to the EU and those shared with the member states.

\section{The Common Commercial Policy in the Treaty of Rome}

As the nascent European Community's raison d'être, trade policy immediately came under supranational competence. In the field of trade, the Treaty of Rome was a revolutionary document. Not only did it contain unusually broad injunctions for achieving free trade internally, it also granted the new supranational entity an external personality with the authority to elaborate, negotiate and enforce all aspects of trade 
relations with the rest of the world. ${ }^{1}$ In practice, this was done through the establishment of a common commercial policy based on three principles: a common external tariff, common trade agreements with third countries, and the uniform application of trade instruments across member states.

Until the 1997 Amsterdam Summit, the Treaty of Rome's original wording of Article $113,{ }^{2}$ which grants the Community exclusive competence in "trade" policy (without defining the term), remained almost unchanged (Devuyst 1992; Maresceau 1993). The provisions determining the trade policy-making process delegated authority from the individual states and their parliaments to the assembly of European states, acting collectively through the Council of Ministers. This approach can be understood in classical principal-agent terms: the member states (principals) have delegated their authority to conclude trade agreements to the European Community (agent), acting on their behalf. This contrasts with areas of "mixed" competence (such as the negotiation of association agreements), where formal authority remains with the individual member states, in particular through parliamentary ratification. In both cases, the member states represent the ultimate authority, but in the former it is as voting parties in the EU structures, while in the latter it is through their sovereign parliament. The conduct of trade policy in practice reveals a second level of delegation, this time from the Council of Ministers (principals) to the European Commission (agent), which initiates the participation of the EU in international trade negotiations and negotiates on behalf of the member states.

\footnotetext{
${ }^{1}$ The 1952 European Coal and Steel Community did not have external powers.

2 Article 113 was renamed Article 133 at Amsterdam.
} 


\section{The challenge to exclusive competence during the 1990s}

During the two decades following the Treaty of Rome, the Commission successfully negotiated on behalf of its members two major trade rounds under GATT, as well as a host of bilateral trade agreements. Throughout the 1980s and 1990s, however, several developments challenged the clear foundations of the Community's trade competence.

The first of these challenges was the emergence of so-called "new issues" (above all services) onto the international trade agenda in the mid-1980s. Issues such as aviation and product standards had been discussed already at the close of the Tokyo Round in 1979, but most member states considered these too domestically sensitive to leave entirely to the Commission. ${ }^{3}$ The subsequent expansion of the world trade agenda onto policies traditionally not "at the border" (e.g. tariffs and quotas) but "inside the state" (e.g. national laws and regulations) forced an explicit internal EU debate on the issue of competence. Several member states, reluctant to give up forever entire new sectors of their trade policy, insisted on being granted their own competences with respect to the “new issues”, arguing that these were not covered under the original Treaty of Rome.

Another challenge was the creation of the new World Trade Organization (WTO), with a broader trade agenda than GATT, which forced the issue of trade authority to the fore (Devuyst 1995). The question of membership constituted an unavoidable legal challenge for the European Community, even though the rest of the world left it up to the Europeans to decide how this would be settled. The EC had never formally substituted

\footnotetext{
${ }^{3}$ At that point, they found a compromise solution whereby the Community concluded all the agreements of the Round, while the ECSC Tariff Protocol, the Standards Code and the Civil Aircraft Code were concluded jointly by the Community and the Member States (Kuilwijk, 1996).
} 
the member states in GATT, whose creation preceded that of the Community. Since the GATT was only an "agreement” with signatories but no members, the question of Community membership never formally arose. For all practical purposes, therefore, the EC --represented by the Commission-- had been accepted by the other GATT partners as one of them. Moreover, formally replacing the member states by the EC could have a cost, since the individual voting rights of member states in GATT would give way to a single vote. ${ }^{4}$

In order to solve the competence dispute, the Commission asked the European Court of Justice for an "advisory opinion” on the issue of competence. If member states were not going to compromise politically, perhaps their objection could be overruled legally. In November 1994, the European judges confirmed that the Community had sole competence to conclude international agreements on trade in goods. ${ }^{5}$ In a controversial move, however, they also held that the member states and the Community shared competence in dealing with trade in the "new issues". ${ }^{6}$ As we have argued elsewhere, the Court in effect had sent the ball back to the politicians (Meunier and Nicolaidis 1999; Nicolaidis and Meunier 2002). To avoid future competence disputes, they would have to amend the treaty either by following the Court's opinion and enshrine this new sharing of

\footnotetext{
${ }^{4}$ Since GATT operated by consensus, this had more symbolic than practical significance.

${ }^{5}$ Including agricultural products and products covered by the European Coal and Steel Community and Euratom treaties.

${ }^{6}$ Court of Justice of the European Communities, Opinion 1/94, 15 November 1994, I-123.
}

(1) The Community has sole competence, pursuant to Article 113 of the EC Treaty, to conclude the multilateral agreements on trade in goods.

(2) The Community and its Member States are jointly competent to conclude GATS.

(3) The Community and its Member States are jointly competent to conclude TRIPs. 
sovereignty in the texts or by explicitly "expanding" Community trade competence to include new issues.

\section{From Amsterdam to Nice: A political solution to the competence dispute}

The resolution of the competence dispute and the revision of Article 113 were tacked onto the broad agenda of the 1996 Inter-Governmental Conference (IGC), which was expected to design an institutional reform that would enable the Union to function with 25 members in the next millennium. Yet the member states could not agree to put the competence issue in trade to rest. The IGC culminated with the signing of the Amsterdam Treaty, in which the member states eventually agreed to a simple and short amendment to Article 113 (renumbered 133) allowing for future expansion of exclusive competence to the excluded sectors through a unanimous vote of the Council. ${ }^{7}$ In trade policy, the Amsterdam outcome was a statement that extension of Community competence should be the result of case-by-case political decisions rather than some uncontrollable spillover. In effect, this decision amounted to a European equivalent of the US's fast track procedures, whereby Congress grants trade negotiating authority to the White House and USTR each time a new round of international negotiations is in sight.

Not surprisingly, it quickly became clear that the Amsterdam compromise on trade was not sustainable. Member states felt compelled to review the trade competence issue once more at Nice in December 2000, so soon after the hardly-fought battle in Amsterdam, for three main reasons. First was the significant increase in trade in services

\footnotetext{
7 The new Article 113 (5) as finally adopted reads as follows: "The Council, acting unanimously on a proposal from the Commission and after consulting the European Parliament, may extend the application of
} 
which had taken place since 1997. In order to capitalize on such growth, Commission trade officials, under the helm of Frenchman Pascal Lamy since September 1999, insisted that trade in services be transferred under the exclusive competence of the Community for reasons of efficiency, especially in view of the upcoming "Millenium round" of multilateral trade negotiations expected to be launched in Seattle in November 2003.

Second, trade had suddenly become a hot political issue, as globalization gave rise to a new brand of well-organized activists worldwide. The defeat of the OECD-based Multilateral Agreement on Investment in 1998 -which aimed to facilitate international investment by ensuring that host governments treat foreign and domestic firms- similarly, was interpreted by anti-globalization activists as a victory against a text that would have limited the ability of national governments to regulate the protection of their culture, environment, natural resources and health, as well as ended the protection of their citizens from foreign investors. Trade was again highly politicized in the summer 1999 when French sheep farmer José Bové and his companions very publicly destroyed a McDonald's in the French countryside in response to the retaliatory trade sanctions that the WTO had authorize the United States to take against the EU in the beef hormones and bananas cases (Meunier 2000a). This politicization of trade reached its peak in December 1999 when the international trade talks in Seattle supposed to launch a new round of multilateral trade talks collapsed, amidst massive public demonstrations by antiglobalization protesters. All of these episodes were reflections and further contributing factors to the increasingly contentious character of trade. ${ }^{8}$ Specifically, anti-globalization

paragraph 1 to 4 to international negotiations and agreements on services and intellectual property insofar as they are not covered by these paragraphs.”

8 Meunier 2000b. 
activists focused their attention on issues such as trade in cultural, education and social services -issues that had been left open to further transfer of competence by the Amsterdam compromise.

Third, the prospect of imminent enlargement of the EU also contributed to calls for revisiting the trade competence issue. Widening membership of the EU to many more countries, all with disparate and even contradictory interests, lent a double sense of urgency to the issue. On the one hand, and most obviously, external representation --like other policy areas-- risked increased inefficiency at best, stalemate at worse. An arrangement originally designed for six members would likely no longer be adequate when the "single voice" has to represent twenty-five different countries. On the other hand, the current members may have had an interest in "locking in" their preferred institutional design before the widening to new members. The prospect of new entrants eager to use their veto power to block trade liberalization in some sectors or, on the contrary, eager to favor liberalization in other areas where existing members would prefer protection may have proven enough of an incentive for the existing members of the EU to settle the institutional question in Nice.

The final agreement reflected the bargaining dynamics of the negotiation. There was a general momentum at Nice to expand qualified majority voting, and article 133 was to be no exception. Exclusive competence became the general rule for trade in services (133.5). Exceptions to exclusive competence in order to satisfy residual national sensitivities were kept to a minimum and carved out under a 'positive list' approach. First and foremost, the Treaty enshrined the concept of "mixed competence" developed by the Court in its 1994 jurisprudence as a new legal category. Particularly noteworthy is 
the explicit inclusion of the "cultural exception" clause in Community law, with cultural and audiovisual services falling under mixed competence alongside education, social and human health services. In addition, transport remained under a separate legal basis (title V and article 300). Finally, intellectual property was divided in two components: “commercial aspects of intellectual property”, which fall under exclusive competence, and all other aspects of intellectual property, which are shared. But the Council could decide by unanimity that the provisions relevant to exclusive competence can be extended to the latter -a last echo of the defunct Amsterdam compromise. ${ }^{9}$ In EU parlance, the "passerelle clause” had now been circumscribed to one last, sensitive, area of trade negotiations.

This outcome proved quite satisfactory for most member states: for France (adamant about cultural exception); for Great Britain (which cared more about the linkage with taxation); for Germany (who is happy about the result for air transport, and whose Länder are content with shared competence on culture); and for the pro-integration countries who can claim that the original spirit of the Treaty of Rome has been, at least to some extent, restored.

\footnotetext{
${ }^{9}$ Article 133, para. 6: "An agreement may not be concluded by the Council if it includes provisions which would go beyond the Community's internal powers, in particular by leading to harmonization of the laws or regulations of the Member States in an area for which this Treaty rules out such harmonization.

In this regard, by way of derogation from the first subparagraph of paragraph 5, agreements relating to trade in cultural and audiovisual services, educational services, and social and human health services, shall fall within the shared competence of the Community and its member states. Consequently, in addition to a Community decision taken in accordance with the relevant provisions of Article 300, the negotiation of such agreements shall require the common accord of the Member States.

The negotiation and conclusion of international agreements in the field of transport shall continue to be governed by the provisions of Title V and Article 300.”
} 


\section{Trade policy in the EU Constitution}

The debate over competence and representation in trade policy was not closed with the Nice Treaty. When a European Convention on the Future of Europe was convened in the Spring of 2002 to draft a constitution for Europe, many voices demanded a greater role for the European Parliament in trade. Indeed, these demands have increased as the reach of trade policy increased to politically sensitive issues that used to be the exclusive domain of domestic regulation, such as food safety and culture. A group of EU parliamentarians filed a constitutional amendment that would give the Parliament unprecedented powers in shaping EU trade policy, including the establishment of a right to a vote of assent in the Parliament for any significant bilateral and multilateral trade deals entered into by the EU. The Commission has also pushed for a greater role for the parliament in trade policy, on the implicit grounds that a right to veto by the Parliament could provide Commission officials with greater leverage in international trade negotiations.

In response to these demands, the Convention introduced many important institutional changes with respect to trade policy -changes which were endorsed by the Intergovernmental Conference which followed and finally agreed on a draft Constitution in June 2004 (to be ratified by 2006). First, the draft Constitution opened up greater avenues for parliamentary control. Trade-related legislation, such as antidumping rules, will now be adopted according to the co-decision procedure -that is, jointly by the Council and the Parliament. The Commission is in charge of the implementation of these rules. The Parliament will be kept informed of the progress of trade negotiations and it will get to approve the conclusion of trade agreements. Formally, this will mean equal 
power of the Council and the Parliament over trade policy. In practice of course, the involvement of the Council through the on-going oversight of Commission activities (see below) still leaves the former in a stronger position.

The second institutional problem faced by the EU has been the challenge of keeping an efficient decision-making system in an enlarged Europe of 25 or even 30 member states. As we have seen, the rule of Qualified Majority Voting did not apply to all cases of trade policy which meant that the existence of a veto could lead to a paralysis of the system. The draft Constitution which goes further than the 2000 Nice Treaty simplifies the trade policy-making apparatus by establishing that trade policy is an exclusive Community competence, whether in goods, services, intellectual property and foreign direct investment. The use of qualified majority voting is broadened correspondingly. There remains however, one exception to this radical symplifaction: l' exception culturelle. Unsurprisingly, all French representatives at the Convention were adamant that matters of trade in cultural and audiovisual services constituted the critical French "red line" and were even supported by a majority of member states, including Germany and Poland. The text actually states that the Council uses unanimity for the negotiation and conclusion of agreements in trade in cultural and audiovisual services when such agreements could jeopardize the cultural and linguistic diversity of the EU. In other cases, majority voting will apply.

If adopted, these institutional changes would make the EU function more effectively across the board. Its trade policy regime more similar to that of the US, where the Congress has the authority to grant negotiating authority to the president and to veto multilateral and bilateral trade deals. Perhaps most importantly, the deal embedded in the 
Constitution would appear to represent a relatively stable equilibrium after a decade of haggling over the precise delineation of powers between the EU and the member states.

\section{The EU trade policy-making process}

How does the EU make decisions in an area which, for all relevant purposes, falls under its prerogative of exclusive competence? The key to this question is to understand the relationship between the Commission and the member states, which can be stylized as a principal-agent relation (Nicolaidis, 2000). We outline below the precise steps and specify the actors involved during each of these steps.

We first need to distinguish between four stages in the negotiation of international agreements: (1) the design of a negotiation mandate; (2) the representation of the parties during the negotiations; (3) the ratification of the agreement once negotiated; and (4) the implementation and enforcement of the agreement once it is brought into force. Figure 1 compares the procedures and the actors in charge at each of these stages in cases of "exclusive" and "mixed" competence. ${ }^{10}$ Whether the Community is perceived to speak with "one voice" is most relevant during the negotiations but is also affected by shared expectations about the ratification stage.

In theory, the core difference between exclusive and mixed competence comes at the ratification stage. Mixed competence in trade simply means that delegation of authority on the part of the member states is granted on an ad-hoc basis for negotiation 
purposes rather than systematically. Individual member states retain a veto both through unanimity voting in the Council and through ratification by their own national parliament. In practice, the difference is more blurred. On one hand, exclusive competence does not guarantee a single voice: Member states might fail to find a majority behind a given policy and if so, their external front may crumble. More to the point, powerful member states still exercise an informal veto both at the mandate and the ratification stages, to the extent that the Luxembourg compromise extends to the trade area. Conversely, member states have managed to speak with one voice in areas of mixed competence or common foreign policy (as exemplified by 95\% of the decisions taken in common in the United Nations). The principle of unity of representation through the Commission is valid under both configurations, even while in both cases, individual member states usually seek to reduce Commission autonomy to the extent tolerated by their partners. Nevertheless, the expression of dissent is dampened, the incentives for seeking compromise increased and the role of the Commission enhanced in areas of exclusive competence.

\section{The negotiating mandate}

The European Commission has the power to propose legislation, act as the guardian of EU treaties, and ensure that EU legislation is implemented by all members. The Commission's role in the EU institutional edifice is to act in support of the collective goals and needs, independently of instructions from national governments. Therefore it is up to the Commission to elaborate proposals for the initiation and content of international

\footnotetext{
${ }^{10}$ We leave out the enforcement stage, which is of lesser importance to our discussion.
} 
trade negotiations (Johnson 1998; Meunier and Nicolaidis 1999; Woolcock 2000; Meunier 2005). The initial proposals are made by staffers in the Trade Directorate ("DG Trade”), based like the rest of the Commission in Brussels. DG Trade assists, and answers to, the EU Trade Commissioner, nominated by the Member States along with the nineteen other commissioners for a five-year term (between 1999 and 2004, the EU Trade Commissioner was Frenchman Pascal Lamy).

Once DG Trade has elaborated proposals for trade negotiations, the key policy discussions take place in a special advisory committee, the "Committee 133," named after Article 133 on trade policy. ${ }^{11}$ It plays a key role in helping member states influence EU trade policy, even though its role is formally consultative only. ${ }^{12}$ The agenda of the Committee 133 is set by the Commission, in collaboration with the rotating presidency of the EU. The Committee 133 meets weekly at either the senior level or at the level of deputies. The senior members (“titulaires”), senior civil servants from the member states' national ministries as well as the director general of DG Trade, meet once a month in Brussels. In addition they meet in Geneva whenever there are WTO plenary sessions. These senior members serve on the committee for extended periods of time and have a good sense of what actions are politically acceptable within their state of origin. They only deal with the politically sensitive problems. The Committee 133 also meets three Fridays a month at the level of deputies, who are drawn from the member states' permanent representations in Brussels, sometimes from the national ministries, in addition to the director of the WTO unit within DG Trade and special experts. The

\footnotetext{
11 The "Committee 133" is named after Article 133 §3.

12 See Raymond J. Ahearn, 2002.
} 
deputies deal with the more technical issues. Additionally, there are also subcommittees of a sectoral nature (such as "133 textiles”, "133 services”, “133 steel”), which prepare the work for the Committee 133. Matters are typically discussed until a consensus emerges and no formal votes are recorded. ${ }^{13}$

The Commission almost always follows the advice of the Committee 133, since its members reflect the wishes of the ministers who ultimately can refuse to conclude the agreement negotiated by the Commission. ${ }^{14}$ Once the Committee has amended Commission proposals, they are transmitted to the Committee of Permanent Representatives (COREPER) -a key group based in Brussels and composed of the member state officials who are national ambassadors to the EU, their deputies and staff. COREPER then transmits the negotiating proposal to the Council of Ministers, which has the power to establish objectives for trade negotiations (known as the "negotiating mandate”). Composed of ministers from each government, the Council represents the national interests of the member states. The composition of the Council varies, depending on the subject matter under discussion. With respect to trade policy, the issues are often tackled by the Council on Foreign Ministers, although sometimes it is composed exclusively of trade ministers.

The Council then agrees on a negotiating mandate to hand out the Commission. The form of the actual mandate varies depending on the negotiation: in some cases the mandate takes the form of one or several directives, while in other cases the mandate is

\footnotetext{
13 The deliberations of the Committee 133 are not published, which is a complaint often raised by antiglobalization groups like ATTAC. But with 26 delegations around the table, secrecy can only go so far...

14 See Fiona Hayes-Renshaw and Helen Wallace, 1997, p. 88.
} 
only a very vague document. ${ }^{15}$ "Negotiating directives" are not legally constraining: the negotiator can depart from those directives, but then takes the risk of having to sell the negotiating package to the Council at the end of the negotiation. Court jurisprudence and treaty articles spell out the cases in which policy decisions are made according to majority or unanimity. According to the 1957 Treaty of Rome, unanimity should have been used for external trade only until January 1966, end of the transitional period. Majority voting would have been automatically instituted after this date, had France's De Gaulle not paralyzed the functioning of Community institutions with the "empty chair" crisis during the Kennedy Round. The crisis resulted in the "Luxembourg Compromise," a gentleman's agreement according to which an individual member state could veto a decision otherwise taken according to qualified majority if it deemed that vital national interests were at stake. ${ }^{16}$ The subsequent addition of new member states increased the divergence of interests within the EC and rendered even more difficult the task of reaching a common bargaining position for international trade negotiations. The 1985 Single European Act attempted to establish the primacy of majority voting. With the exception of sensitive areas such as taxes, employee rights, and the free movement of persons, the member states agreed to use majority voting to legislate on all economic matters. ${ }^{17}$ Since then, at least on paper, the Council agrees on a common external bargaining position for international trade negotiations on "traditional" trade issues (exclusive of services and intellectual property) according to a "qualified majority"

\footnotetext{
${ }^{15}$ On the formal vs. informal shapes of the negotiating mandate in trade policy, see Kerremans 2003.

${ }^{16}$ See Garrett 1995 on the Luxembourg Compromise and the various legislative procedures today. See Chapter 3 of this book for an analysis of the historical relation between the Luxembourg Compromise and the Kennedy Round of trade negotiations.
} 
system. This is a procedure under which member states are assigned different voting weights, based approximately on the size of their population, and by which roughly twothirds of the votes are needed in order for a proposal to be accepted. ${ }^{18}$ Nevertheless, in reaching a common bargaining position for international trade negotiations as in reaching most other policy decisions in the Community, member states have most often attempted to find a general consensus around a given issue without resorting to a formal vote. ${ }^{19}$.

The competence over external trade negotiations is therefore fairly centralized at the Commission and Council levels. Unlike in other fields of external agreements, such as the association agreements, the European Parliament has no formal say in the process. Subsequent Treaty modifications, such as the 1986 Single European Act, the 1991 Maastricht Treaty, the 1997 Amsterdam Treaty and the 2000 Nice Treaty have not increased the role of the Parliament in the trade policy-making process. In practice,

\footnotetext{
${ }^{17}$ See Moravcsik 1991 on the issue of voting in the Single European Act.

${ }^{18}$ From 1995 to 2003, Germany, France, Italy and the United Kingdom each had 10 votes; Spain 8; Belgium, Greece, the Netherlands and Portugal 5; Austria and Sweden 4; Ireland, Denmark and Finland 3; and Luxembourg 2. 62 votes out of a total of 87 votes needed to be cast in its favor for a Commission proposal to be adopted. In other cases, the qualified majority remained the same but the 62 votes had to be cast by at least 10 member states. The qualified majority requirements were changed by the 2004 Accession Treaty. A qualified majority will be obtained if the decision receives at least a specified number of votes and the decision is approved by a majority of Member States. The weighing of the votes was also changed. See for instance http://www.europa.eu.int/comm/igc2000/dialogue/info/offdoc/guidecitoyen_en.pdf for a table of the new voting weights, including those of the candidate countries.

19 In 1994 only 14\% of the legislation adopted by the Council was formally put to a vote and subject of negative votes and abstentions (source: Guide to EU institutions, The Council, EUROPA web server). Moreover, while in theory the consultation procedure (under which Commission proposals can be amended by the Council only unanimously) applies, in practice the Commission alters its proposal several times following the deliberations of the 133 Committee in order to ensure adoption by the Council (Garrett and Tsebelis 1998 argue that the consultation procedure gives the agenda-setting Commission the possibility to act strategically in presenting its proposals to the Council). Even during the height of the crisis created by French demands for a renegotiation of the Uruguay Round agricultural agreement between the EU and the US in 1993, member states insisted that the tradition of consensus be not broken. See also Devuyst 1995; Paemen and Bensch 1995; and Woolcock and Hodges 1996 on the EC negotiating process during the Uruguay Round.
} 
informal procedures exist for informing and consulting the Parliament: the Commission and the Council inform the Parliament of the conduct of international trade negotiations on an informal basis and may request the Parliament's approval before the formal ratification of an international agreement. Nevertheless, while it cannot veto trade legislation (unlike legislation in social policy, agriculture, and the internal market), the Parliament can hold hearings and issue reports on trade issues, thereby influencing indirectly the course of trade negotiations. Lately it has tried to exert greater clout over trade, especially those issues with a heavy regulatory component that have divided the EU and the US. ${ }^{20}$ The European Parliament was indeed the driving force behind the EU ban on aircraft engine hushkits to meet noise standards, data protection issues that affect US firms, and broadcast and motion picture quotas. Perhaps this will marginally change if the EU Constitution is adopted.

\section{The negotiations}

Following the adoption of the negotiating mandate by the Council, the actual conduct of international trade negotiations for the EU is carried out by members of the Commission, acting under the authority of the Trade Commissioner. The situation during the negotiations may seem somewhat surrealistic: member states are allowed to observe but not speak in WTO plenary sessions. In principle, as long as they remain within the limits set by the mandate, Commission negotiators are free to conduct bargaining with third countries as they wish. In practice the negotiators' latitude and flexibility vary case by

20 See Ahearn, 2002. 
case, depending on the member states' willingness to give up control over the issue being negotiated. While they remain silent in plenary, member states ambassadors usually do not shy away from informal corridor negotiations with EU counterparts. Moreover, the Committee 133 often meets in Geneva during the negotiations to ascertain whether the Commission remains with its mandate and to agree on changes in negotiating position. Thus if the EU Commissioner is envisaging a significant move, he needs to either call the capitals or call a meeting on the premise of the negotiations. This oversight often makes moves and concessions harder for the EU than for other trade partners, but it also gives it significant bargaining power (Meunier 2000b; Meunier 2005). From the member states’ viewpoint, it is this oversight that makes it acceptable to issue vague mandates containing little indication of the actual positions to be taken in negotiation.

\section{The ratification}

At the conclusion of the negotiations, the trade agreement must be ratified. In cases of agreements falling entirely under EU competence (such as on textiles and steel), the Council approves or rejects the final text according to qualified majority voting -with the exception of some services and intellectual property negotiations where unanimity is the rule (Meunier 2005). In most cases, however, the ratification process is complicated by the "mixed" nature of many of the big, "packaged” trade agreements, which must be approved both by the EU as a whole and by the individual Member States. EU ratification occurs through adoption in the Council. As for Member States, they ratify the trade agreement according to their own internal procedures, such as a vote in parliament. In practice, the Council always decides on the temporary implementation of the EU-only 
part of the agreement. The rest, subject to national ratification, is implemented later, often years. Hence, there is no room for big surprises at the ratification stage of the negotiation, since Member States have had ample time to manifest their reservations during the course of the international negotiations.

\section{The enlarged EU as a trade power}

The EU enlarged to ten new countries in May 2004, the biggest enlargement ever since its creation. This did not trigger any immediate disruption of trade, since the transition had been prepared for a decade. Indeed, on the eve of enlargement, over $95 \%$ of the trade of the EU-15 with the new entrants was already free.

Structurally, enlargement will make the EU stronger in relation to its trade negotiating partners, because a larger single market is both a more attractive prize to outside economic players and a more costly opportunity loss in cases when a threat of being cut out is carried through. Enlargement increases the size of the single market (accounting for $18 \%$ of world trade and contributing to $25 \%$ of the world's GDP), augments the geographical size of the EU by 34\%, and boosts the total population by 105 million to a total of $\$ 450$ million. ${ }^{21}$

By joining the EU, however, the new entrants are bringing in a wealth of different histories and cultures, which also means different interests, priorities and sensibilities. These will have to be included and amalgamated in the definition of a common European

\footnotetext{
21 Source: Commission of the European Communities, "Trade implications of EU enlargement: Facts and Figures.” Brussels, 4 February http://europa.eu.int/comm/trade/issues/bilateral/regions/candidates/ff040204_en.htm
} 
position on trade, thus posing a challenge to the current institutional mechanisms. Pessimists argue that diversity could incapacitate the EU and bog down multilateral trade liberalization. Substantively, they say it could also lead to common positions which are invariably the lowest common denominator and, therefore, to a protectionist bias of the EU in international trade negotiations. On the other hand, there is no doubt that through sheer arithmetics, enlargement will make internal EU negotiations more difficult to control for trade ministers; it can be argued that this in turn could further concentrate trade policy-making power in the hands of the Commission, which has a historical and functionalist interest in promoting trade liberalization (Van den Hoven 2002). In short, the impact of the new members on the balance between protectionist and liberal forces in the EU overall is under-determined.

Undoubtedly however, EU enlargement raises several legal and political issues. For instance, the US and the new entrants have bilateral agreements on investment protection that do include provisions contrary to Community law (for instance with respect to investments in the audiovisual sector). Another issue is the negotiation which necessarily follows from the extension of the customs union to ten currently autonomous territories (known as Article 24 negotiation). In most cases, third countries will benefit from a drop in custom duties. Official EU calculations predict that enlargement will lead, overall, to a reduction in average tariffs from 9 to $4 \% .{ }^{22}$ In some highly visible cases, however, the pre-enlargement custom duties of the new entrants are lower (when not null) than those of the EU - leading to a raise after May 2004 and thus presumably trade

\footnotetext{
22 Source: Commission of the European Communities, "Trade implications of EU enlargement: Facts and Figures.” Brussels, 4 February 2004.
} 
frictions, in particular with the United States (similar to the "chicken war" of 1963). Independent calculations show that enlargement will indeed lower industrial tariffs in the new entrants, but it may nearly double tariffs on agriculture, especially for products such as wheat, beef, and dairy products, which are all important in the EU trade policy at the WTO (Van den Hoven 2002).

From a political perspective, one could expect the new entrants to pursue a general policy line more favorable to the United States, as was suggested by Secretary Rumsfeld's quip on "old Europe, new Europe” at the time of the Iraq war: it would seem that "new Europe" is more open to the US economically as well as politically. But while the US administration can certainly be expected to pursue its strategy of "divide and rule", the extension of qualified majority voting should limit the incidences when such tactics can work since it is getting harder to muster a blocking minority. On some issues, however, the new entrants will likely have trade interests contrary to those of the US. Analysts expect Poland and several other new entrants to become strong supporters of anti-dumping measures for basic industrial goods such as steel, chemicals and textiles (Messerlin 2001; Van den Hoven 2002; Evenett and Verlmust 2004). Moreover, the countries that stand to benefit most from the generous EU agricultural provisions will not be inclined to make concessions on that issue. Once they gain access to CAP subsidies, they may likely strengthen the protectionist camp in the agricultural sector. Finally, since the services sector is still relatively weak in these countries, this may weaken internal EU support for greater services liberalization in the WTO (Van den Hoven 2002). 


\section{The EU as champion of multilateralism?}

We have now illustrated how almost all of trade policy falls under the exclusive net of the EU; how, under this configuration, the Commission negotiates on behalf and under the control of member states; and the potential impact of enlargement on those dynamics. How, then, does the EU exercise its formidable power in trade policy? We argue that it has been by asserting its central role in the multilateral system, less to uphold the value of multilateralism as a public good and more to promote the EU's own interest in this system. The EU has always claimed that its single market is a building block for multilateralism and often posits itself as champion of international law, including in the field of global economic governance (by contrast to the United States, for instance). Yet, it does continue to attract criticism. Can it genuinely pretend to defend developing countries in view of the amount of subsidies poured into its protectionist agricultural policy? Is it nor the case that its highly differentiated approach to trade agreements around the world constitutes undue discrimination? Is the EU not trying to impose its own regulatory model as a condition for free trade instead of negotiating with world partners on an equal footing?

\section{The European single market and world trade liberalization}

From its inception, the EU has played a central role in multilateral trade negotiations (Woolcock 1993; Young 2000, 2002; Smith 2001; Meunier 2005). In the 1960s it introduced a new radical tariff-cutting formula which greatly reduced the transaction costs of negotiations. In spite of the rising trend of "new protectionism" in the 1970s, the Europeans led the way in attacking so called non-tariff barriers. As the EU accelerated 
the pace of completion of its single market in the run-up to 1992, issues became more complicated. Quite logically, it required that firms wishing to export goods and services into the EU conform to its standards and regulations as well as to its conformity assessment procedures (Mattli and Buthe 2003). Since such requirements had not been consistently enforced before, the move initially spurred cries of "fortress Europe" indeed the external dimension of the single market had been dealt with a bit as an afterthought. But quickly, the EU Commission sought to ensure that foreign firms be given a fair chance of access through opportunities to demonstrate their conformity to standards (Nicolaidis and Egan 2001).

As the programme to complete the single market agreed to under the Single Act (1987-1992) coincided with the Uruguay Round (1986-1993), the EU progressively developed a strategy to export its approach to trade liberalization to the global level, especially in dealing with trade in services, the core new area in both settings (Drake and Nicolaidis 1992). Along with the US, it promoted the inclusion of "new issues" (services, intellectual property rights, and trade related investment measures) under the WTO which was created at the end of the Uruguay Round. Agriculture, however, has remained the glaring counter-example of liberalization. By the end of the Uruguay Round in 1993, the EU did not look so good as a trade liberalizer, as the trade distortions engendered by the CAP led the US to build a coalition of GATT members against the European agricultural 
policy (Patterson 1997; Davis 2003). The Cairns group on its part mobilized against both US and EU farming support. ${ }^{23}$

But the issue is not only how much liberalization, but also what kind of liberalization and for whose benefit. During the 1990s, the developing world progressively came to question the "grand bargain" agreed to during the Uruguay Round - namely, accepting to open up their markets to services and to enforce patents in exchange for greater access for their industrial products. The cost of the former turned out to be higher than many had foreseen while increased access for third world exports often failed to materialize. Initially both the US and the EU resisted their attempt to revisit this bargain while at the same time pushing for a continued expansion of the multilateral agenda to include issues such as linkage between trade access and labor and environment standards. The tension between OECD countries - including the EU - and the developing world culminated at Seattle in 1999. But in the years since, the EU has managed to establish, at least partly, a new reputation as a champion of multilateralism. Today it is the EU who is mobilizing WTO members against the perceived US unilateralism on issues such as steel, taxation, and anti-dumping. Most importantly, the EU played a key role in launching the "Doha development agenda", in November 2001, the first trade round avowedly aimed specifically the welfare of the developing countries. There it promoted the adoption of a path-breaking declaration on trade and public health which opened the way for legalizing broad exemptions from intellectual property constraints by importing generic drugs to treat diseases like AIDS (a final agreement was

\footnotetext{
23 The Cairns Group, founded in 1986, is a coalition of 17 agricultural exporting countries accounting for one-third of the world's agricultural exports. Its members are Argentina, Australia, Bolivia, Brazil, Canada,
} 
finally accepted by the US in August 2003). Moreover, the EU sought to take the lead in making good on market access by launching in the run-up to the Doha Round, the "Everything but Arms" initiative (EBA), designed to offer preferential market access to the exports of the 48 least developed countries in the world. This initiative enabled the EU to change its image in the WTO by holding the high moral ground, even though it was not able then to have its approach adopted by the entire WTO membership.

Many voices, however, question the EU's genuine commitment to putting multilateralism at the service of development. Agriculture has at last become central stage in the Doha round, with developed countries being asked to reduce (if not eliminate) their trade-distorting farm subsidies and drastically decrease their tariffs, quotas, and non-tariff barriers. While the EU and the US had reached a common proposal on reform of the protection of their agriculture, this was not enough. The collapse of the WTO Cancun meeting in September 2003 was due to a great extent to differences over agricultural reform, especially over the issue of cotton, between the US, the EU and a group of developing countries led by Brazil and India (called the G-22). Perhaps more fundamentally, the meeting exposed a clash between an EU philosophy of trade liberalisation based on the design and enforcement of new multilateral rules reproducing the EU's own approach (the so-called "Singapore issues" --investment, competition policy, government procurement, and trade facilitation) and the approach of most of the rest of the world, which continues to view trade rounds as fora for the exchange of reciprocal conditions. The abrupt end of the Cancun meeting testifies to this tension and left a great deal of uncertainty on how to proceed next with talks on agriculture, industrial

Chile, Colombia, Costa Rica, Guatemala, Indonesia, Malaysia, New Zealand, Paraguay, the Philippines, 
goods, and the Singapore issues when agreements need to be reached in a consensual way in an organization with 148 members.

In what direction is EU trade policy evolving? In the Spring 2004, the EU made bold proposals in order to relaunch the multilateral trade talks. Most importantly, it offered to put on the table all agricultural export subsidies, provided that others do the same and that the final agreement offer an overall balanced package on agriculture. For decades the issue of agricultural export subsidies had been a sticking point in multilateral trade negotiations, so this is close to a revolutionary proposal (even if it is easy to argue that, in the long run, the EU has little choice but giving these up). The second EU proposal was to be more flexible on the so-called Singapore issues, which may mean abandoning them in the end, since most countries are not ready to launch multilateral negotiations on investment, competition and public procurement. Finally, the EU proposed to give a special deal to the 90 poorest countries in the world, which could benefit from freer access to world markets while not opening up further their own markets. In August 2004, the Doha Round participants adopted a package of temporary agreements including commitments, such as the abolition of agricultural export subsidies.

South Africa, Thailand and Uruguay.. 


\section{Box 12.1:EU trade policy instruments}

Trade Policy Instruments

The EU Commission, through DG Trade, also oversees the use of trade policy instruments, which are of the defensive and the proactive types.

Defensive instruments: “Trade Defense Instruments" (TDI) may be used to counter unfair trade practices by other countries, in accordance with WTO agreements. They consist of:

- Anti-dumping measures: used to counter dumping, which occurs when manufacturers from a non-EU country sells goods in the EU below the sales price in their domestic market or below the cost of production -this is the most frequent trade-distorting practice.

- Anti-subsidy measures: used to combat subsidies, which help to reduce production costs from abroad or cut the price of EU exports, with the consequence of distorting trade.

- Safeguards: the WTO allows a country to restrict temporarily imports of a product if its domestic industry is seriously injured by a surge in imports.

Proactive instruments: the “Trade Barriers Regulation” (TBR) enables companies to lodge a complaint with the EU Commission when they feel they encounter trade barriers that restrict their access to third country markets.

Source: http://europa.eu.int/comm/trade/issues/respectrules/tpi_en/htm 


\section{Settling disputes in the WTO}

The WTO differs from its predecessor, the GATT, not only because it is a bona fide organization rather than a mere "agreement" with a broader scope, but also and perhaps most importantly due to its significantly strengthened dispute settlement mechanism, in which the EU has been an active participant. In 2004, the EU was involved in 29 WTO disputes as both a plaintiff (16 cases) and a defendant (13 cases) with 8 of its trading partners (Argentina, Australia, Brazil, Canada, India, Korea, Thailand and the US). ${ }^{24}$ In the majority of these cases (14 out of 29), the EU was paired against the US -11 times with the EU as the plaintiff (e.g. US Anti-Dumping Act and Foreign Sales Corporation) and only 3 times with the EU as the defendant (GMOs, hormones, and trademark/geographical indications).

Such a high level of involvement has strengthened overall the power of the EU in trade. On one hand, some of the EU's trade partners have exercised their rights to demand change in EU trade practices (such as on hormone-treated beef and bananas), which has resulted either in compliance or in the willingness by the EU to incur retaliatory sanctions. On the other hand, participation in the WTO has enabled the EU to confront other trade partners, in particular the US, on a variety of unilateral actions. The following examples of recent and ongoing transatlantic trade disputes are evidence of the power of the EU in the multilateral trade arena.

\footnotetext{
24 EU Commission, "General overview of active WTO dispute settlement cases involving the EC as complainant or defendant”, Brussels, 7 April 2004.
} 
Steel: In the Spring 2002, the Bush administration unilaterally raised steel tariffs for a three-year period by $30 \%$ in order to protect its domestic steel industry from the problem of global overcapacity during a time of restructuring. The EU (and seven other countries ${ }^{25}$ ) launched a lawsuit at the WTO, which ruled that the tariffs were in violation of international trade rules. The WTO confirmed in November 2003 in its final ruling that the American tariffs are indeed illegal under international trade rules. Faced with threat that Europe would impose $100 \%$ duties on $\$ 2.2$ billion worth of US imports, ranging from Harley Davidson to underwear to citrus juices from Florida-- products chosen mainly because coming from swing-states crucial for next year's US presidential election - Washington dropped the tariffs in December 2003.

Tax breaks: In 2000 the EU asked the WTO to adjudicate on the so-called Foreign Sales Corporation (FSC) dispute, because this American law was believed to confer illegal export subsidies to many US companies by taxing exports more favorably than production abroad. In subsequent rulings, the WTO confirmed that the FSC indeed constituted an illegal export subsidy and gave the US administration until November 2000 to withdraw its scheme. The US replaced the FSC law, but because the new law did not substantially modify the export subsidy scheme, the EU challenged it again in the WTO. In 2002 the WTO ruled again that these breaks were indeed an illegal subsidy and authorized the EU to impose $\$ 4$ billion in retaliatory sanctions if the US law was not brought in compliance with WTO obligations. The Europeans, fearful of what the sanctions would do to their own economies given the size of the potential disruption to transatlantic trade (more than ten times larger than the beef and bananas sanctions

\footnotetext{
25 Japan, South Korea, Norway, Switzerland, China, New Zealand and Brazil.
} 
combined), opted for patience and instead gave the Americans ample time to change their tax laws. In March 2004 the EU began to gradually implement some retaliatory sanctions on American exports. The law repealing the FSC was finally passed in October 2004 and is supposed to be implemented as of 2005 (with a transitory period). The EU will lift the sanctions when the implementation of the new US law proves satisfactory.

Anti-Dumping: In 2000 the WTO condemned the US 1916 Anti-Dumping Act for allowing sanctions against dumping not permitted under WTO agreements and gave the US one year to repeal the Act.. In February 2004, given the non-compliance of the US, the WTO allowed the EU to retaliate by implementing a mirror regulation that would be applicable only to American products.

Genetically modified organisms: Since 1998, the EU has observed a moratorium on the approval of GMO products, and some member states banned the import and cultivation of some crops that had been approved prior to that date. The EU made this decision in response to popular concern about the long-term impact of GMOs on human health and the environment, although there was little scientific evidence to support these concerns, but no evidence either that GMOs are harmless (Pollack and Shaffer 2000; Vogel 2002; Rhinard 2004). This measure led to the suspension of exports of genetically modified corn from the US. The successive American administrations were hesitant at first to challenge at the WTO the issue of whether such public health concerns could legitimize protectionism. In May 2003, however, the Bush administration decided to finally file the suit against the EU at the WTO when it was learned that the EU warned Zambia to refuse US donations of genetically modified corn and that many poor African nations refused to experiment with GMO crops for fear that they could not sell them in 
Europe. Such a lawsuit, however, is politically risky. It may spark a backlash from European consumers, already quite nervous over food safety in the wake of the mad cow and foot and mouth diseases, and perhaps some consumer resistance in the US as well. 


\section{“Open bilateralism”? The limits of transatlantic trade cooperation}

In spite of these disputes, the transatlantic trade partnership is characterized by a much greater degree of cooperation than conflict, owing to the unprecedented level of interdependence between the two sides of the Atlantic: in 2003 EU imports from the US represent a fifth of its imports while EU exports to the US represented a quarter of US exports. ${ }^{26}$ While transatlantic economic cooperation is not new, the post cold war era has been characterized by a much greater emphasis over economic and regulatory cooperation than ever before and the growing recognition by the US of the importance of the EU as an interlocutor over and above the member states (BP Chair Report, 2001). In the wake of the disputes surrounding the completion of the single market mentioned above the EU and the US signed a series of agreements to underpin their new transatlantic partnership - the Transatlantic Declaration (1990), the New Transatlantic Agenda (NTA, 1995), and the Transatlantic Economic Partnership (TEP, 1998). The idea of a Transatlantic free trade area was quietly abandoned given its potential implications for agriculture, as well as grander schemes for the total elimination of all industrial tariffs. Instead, these agreements served both to increase the scope of cooperation (creating a "transatlantic marketplace") and to introduce more formal institutions to manage such cooperation. Especially with the NTA, and at the urging of the Transatlantic Business Dialogue, a special focus was introduced on regulatory cooperation to allow the trading partners to overcome their non-tariff barriers to trade.

\footnotetext{
26 Source: EU Commission 2 DG http://europa.eu.int/comm/trade/issues/bilateral/countries/usa/index_en.htm.
} 
One of the most innovative aspects of the new transatlantic cooperation was the signing in 1997 of a series of "Mutual Recognition Agreements", from pharmaceuticals to telecoms. These agreements were certainly less ambitious than their inspirators -the mutual recognition directives enforced to complete the internal market of the EU - in that they only covered the recognition of conformity assessments rather than recognition of the standards themselves (Nicolaidis and Egan 2001). But the difficulty of signing on to such agreements should not be under-estimated. US agencies like the Food and Drug Administration had to undergo a great deal of pressure before agreeing to transfer part of their regulatory authority to their EU counterparts. And accommodating the complex array of conformity assessment bodies operating in the US for electrical standards and the likes to the more coordinated system prevailing in the EU was no small feat. In fact it has proven impossible to extend the MRA approach beyond the original six to other products or to services where the US is notoriously plagued by regulatory fragmentation due to its federal structure.

In fact the EU has successfully negotiated a whole array of MRAs around the world, spearheading a movement towards trade-friendly regulatory reform without deregulation. Whether its approach can serve as a laboratory for regulatory cooperation under WTO remains to be seen (Nicolaidis and Howse, 2002).

\section{The EU's conditional support for Regionalism}

Last but not least, the EU has built over the last decade a complex web of preferential agreements which has come to encompass most of the planet. For several decades, the EU negotiated trade agreements only with its immediate neighbors (mainly to the East) 
and the former colonies with which it shared historical ties, mainly through the successive Lomé (later Cotonou) conventions. Since the end of the Uruguay Round, which coincided with the signing of the North American Free Trade Agreements, the EU has become actively interested in negotiating regional agreements with a variety of other countries, mostly in Latin America, where the EU has signed "Global Agreements" (including free-trade) with Mexico in 2000 and Chile in 2002 (Sbragia 2004). An allencompassing agreement with the customs union Mercosur (Argentina, Brazil, Paraguay and Uruguay), aiming at the creation of a free-trade area with the European single market, is currently being negotiated. If concluded, this would be the first agreement between two customs unions. The EU has also signed regional association agreements through the 1995 Euro-Mediterranean partnership (also referred to as the "Barcelona Process”), with the goal of establishing a Euro-Mediterranean Free Trade Area by $2010 .{ }^{27}$ The EU has also negotiated a free trade agreement with South Africa in 2000.

\section{Box 12.2:The Barcelona Process}

The partnership between the EU and the Mediterranean countries is referred to as the 'Barcelona Process'. In the 1995 Barcelona Declaration, the then 27 EuroMediterranean Partners agreed on the establishment of a Euro-Mediterranean Free Trade Area by 2010, to be achieved through Association Agreements, negotiated and concluded with the European Union, together with free trade agreements between themselves. These $\underline{\text { association agreements also include respect for human rights and democratic principles as }}$

\footnotetext{
27 The signatories to the agreements are Algeria, Cyprus, Egypt, Israel, Jordan, Lebanon, Malta, Morocco, Palestinian Authority, Syria, Turkey, and Tunisia.
} 
essential elements. More recently it has been decided to add clauses on fighting Terrorism, and on Non proliferation of Weapons of Mass Destruction.

In addition to the EU member states, the parties to the Barcelona Process are: Algeria, Cyprus, Egypt, Israel, Jordan, Lebanon, Malta, Morocco, Palestinian Authority, Syria, Turkey, and Tunisia

Source:

http://europa.eu.int/comm/trade/issues/bilateral/regions/euromed/index_en.htm

This active pursuit of regionalism through bilateral agreements further reinforces the EU as a global power. In part a forced reaction to the US' move towards regionalism in the 1990s, the new policy has increased EU power by restoring a level playing field for European companies competing in the lucrative Latin American markets. Regionalism has also enhanced the EU's normative power. In a way, the EU has acted as a “globalizer” with Latin America, exporting its cultural and political dimensions along with its economic agreements (Sbragia 2004).

\section{Conclusion: The EU as a power in and through trade}

The EU is a formidable power in trade. If it is considered as one single economic unit, there is little doubt that it has become, after the last enlargement, the biggest trading block in the world. As a result its potential hegemonic power, based on the capacity to 
grant or withhold access to its internal market, has become as strong as the US. Moreover, its more than forty years of experience negotiating international trade agreements on behalf of its members have made the EU an essential player and a powerful bargainer in the multilateral trading system.

The EU is also becoming a power through trade. Increasingly, it uses market access as a bargaining chip to obtain changes in the domestic arena of its trading partners, from labor standards to development policies. Indeed, one of the central objectives of EU trade policy under the helm of trade commissioner Pascal Lamy has been to "harness globalization” and spread, through the negotiation of trade agreements, the European model of society to the rest of the world. One of the most interesting questions about European trade policy today is how far the EU will be willing or able to transform its structural power into effective influence and what will be its goals in establishing itself as a global power through trade. In particular, can the EU become an important foreign policy actor through the back door, by using trade instead of more traditional diplomatic or military means? As the 2004 bilateral agreement with Syria seems to indicate, the EU is now entering a new phase where it is increasingly ready and able to use its trade muscle to serve political goals, in this case controlling the proliferation of weapons of mass destruction. It remains to be seen, however, how effective such a policy will be in the long run, and whether the EU can escape the adjacent risk of (even benign) imperialism which comes from seeking to impose one's model onto the rest of the world. 


\section{Further Reading}

The following is a selection of the very substantial literature about the EU's trade policies, which reflects both the legal and the policy analysis aspects of the topic. Some historical background is provided by Devuyst (1995), Johnson (1998), Woolcock (1993) and Young (2000, 2002). The specific issues of competence and of the trade policy process (including WTO negotiations) are dealt with by Meunier (2000, 2005), Meunier and Nicolaidis (1999), Nicolaidis and Meunier (2002), Smith (2001) and Woolcock (2000). Smith (2001) and Young (2002) provide analysis of the ways in which the changing nature of world trade has been reflected in EU trade policies.

Devuyst, Y. (1995), 'The European Community and the Conclusion of the Uruguay Round' in Rhodes, C. and Mazey, S. (eds) The State of the European Union, vol. 3 (Boulder, CO: Lynne Rienner).

Johnson, M. (1998), European Community Trade Policy and the Article 113 Committee (London: Royal Institute of International Affairs).

Meunier, S. (2000), "What single voice? European institutions and EU-US trade negotiations." International Organization 54/1, pp. 103-35.

Meunier, S. (2005), Trading Voices: The European Union in International Commercial Negotiations (Princeton, NJ: Princeton University Press).

Meunier, S. and Nicolaidis, K. (1999), 'Who speaks for Europe? The delegation of trade authority in the EU', Journal of Common Market Studies 37/3, pp. 477-501. 
Nicolaidis, K. and Meunier, S. (2002), 'Revisiting Trade Competence in the European Union: Amsterdam, Nice, and Beyond', in Hosli, M., van Deemen, A. and Widgren, M. (eds) Institutional Challenges in the European Union (London: Routledge).

Smith, M. (2001), 'The European Union's Commercial Policy: Between Coherence and Fragmentation', Journal of European Public Policy 8/5, pp. 787-802.

Woolcock, S. (1993), 'The European Acquis and Multilateral Trade Rules: Are They Compatible?' Journal of Common Market Studies 31/4, pp. 539-558.

Woolcock, S. (2000), 'European Trade Policy' in Wallace, H. and Wallace, W. (eds) Policy-Making in the European Union (Oxford: Oxford University Press), pp. 373-400.

Young, A. (2000), 'The Adaptation of European Foreign Economic Policy: From Rome to Seattle' Journal of Common Market Studies 38/1, pp. 93-116.

Young, A. (2002), Extending European Cooperation: the European Union and the 'new' international trade agenda (Manchester: Manchester University Press).

\section{Web links}

The first port of call for all matters of EU trade policy is the web site of EU Commission, DG Trade: http://www.europa.eu.int/comm/trade/ . Much useful information about the context for and the impact of EU trade policies can be obtained from the World Trade Organisation and Organisation for Economic Cooperation and development web sites: World Trade Organization: http://www.wto.org/ :OECD: http://www.oecd.org/home/ . A good web site providing information and analysis about trade policies and the global 
political economy is that of the Washington based Institute for International Economics:

http://www.iie.com/. 